\title{
THE IMPLEMENTATION OF MADRASA CULTURE IN BUILDING STUDENTS' CHARACTER
}

\author{
Warti'ah \\ Sekolah Tinggi Agama Islam Daruttaqwa Gresik Indonesia \\ wartiah16061971@gmail.com
}

Received: 01-02-2020

Revised: 07-07-2020

Accepted: 23-07-2020

\begin{abstract}
This study aims to determine the implementation of madrasa culture to build character of students in Madrasah Ibtidaiyah Ma'arif NU Manba'ur Rohmah Gresik. This Research using qualitative methods with a descriptive approach, collecting data through observation, interviews and documents. While the research informants are the Principal, Teachers and parents of students. The results of this study indicate that the Madrasah Ibtidaiyah (MI) Ma'arif NU Manba'ur Rohmah Gresik in shaping the character of students through the book monitored the mercy of the Merciful Mimbar of Love. In shaping the character through madrasa culture, namely: 1) Koran day, this culture is done to get students accustomed to reading the Koran every day; 2) Dhuba prayer, culture to accustom students to always do Dhuha prayer every day; 3) Istighotsah, culture to accustom students to always pray closer to God; 4) Literacy, the culture of reading is instilled in students so that reading can add insight into knowledge.
\end{abstract}

Keywords: Madrasah Culture, Character, Implementatiton

\section{Abstrak}

Penelitian ini bertujuan untuk mengetabui implementasi budaya madrasah dalam membentuk karakter siswa di Madrasah Ibtidaiyah Ma'arif NU Manba'ur Rohmah Gresik. Mengunakan metode kualitatif dengan pendekatan diskriptif, pengumpulan data melalui observasi, wawancara dan dokumen. Sedangkan informan penelitian yaitu Kepala Sekolah, Guru dan orang tua murid. Hasil penelitian ini menunjukean bahwa Madrasah Ibtidaiyah (MI) Ma'arif NU Manba'ur Rohmah Gresik dalam membentuk karakter siswa melalui buku pantau akblakul karimah Mimbar Penuh Kasih Sayang. Dalam membentuk karakter tersebut melalui budaya madrasah yaitu: 1) Qur'an day, budaya ini dilakukan untuk membiasakan siswa selalu membaca Alqur'an setiap hari; 2) Sholat dhuba, budaya untuk membiasakan siswa selalu melaksanakan sholat dhuba setiap bari; 3) Istighotsah, budaya untuk membiasakan siswa untuk selalu berdo'a mendekatkan diri kepada Allah; 4) Literasi, budaya membaca ditanamkan pada siswa sehingga dengan membaca dapat menambah wawasan pengetahuan.

Kata Kunci: Budaya Madrasah, Karakter, Implementasi

\section{INTRODUCTION}

National education functions to develop capabilities and shape the dignified character and civilization of the nation in the context of developing the intellectual life of the nation, aiming at developing the potential of learners to become people of faith and devotion to God Almighty, having noble, healthy, knowledgeable, capable, creative, independent , and be a democratic and responsible citizen (Law number 20 of 2003). While the purpose of basic 
education is to lay the foundation of intelligence, knowledge, personality, noble character, and the skills to live independently and follow further education ${ }^{1}$.

Every organization in any form has its own personality that distinguishes it from other organizations $^{2}$. The formation of a distinctive personality that does not immediately exist when the organization was founded ${ }^{3}$. However, it takes a longer time for the organizational process to grow and develop. In every development of the organization it will find its identity, and have its own personality that is not shared by other organizations ${ }^{4}$.

One factor that distinguishes an organization from other organizations is its culture. This is important to be understood by everyone in the organization ${ }^{5}$. Every person who initially comes to any organization with a personal culture, must immediately learn the culture of the organization concerned to see what adjustments are necessary and must be done. Therefore everyone in an organization must be able to follow the organizational culture in their organization ${ }^{6}$.

Organizational culture is the main thing in various organizations both educational and non-educational organizations. Organizational climate will be conducive if the organizational culture applied within the organization has a strong influence on the organizational climate so that the organization becomes effective. In realizing a good educational organization, the organizational culture in the organization must be truly created, implemented, maintained and developed to suit the internal and external demands of the organization?

1 M. Haviz et al., "Investigating Students Knowledge and Social Awareness of the Community of Religious Social Activist Minangkabau: A Community Based Reseach In West Sumatra, Indonesia," TARBIYA: Journal of Education in Muslim Society 6, no. 1 (December 29, 2019): 10-22, https://doi.org/10.15408/tjems.v6i1.8657; Hasan Baharun and Rohmatul Ummah, "Strengthening Students' Character in Akhlaq Subject Through Problem Based Learning Model," Tadris: Jurnal Keguruan Dan Ilmu Tarbiyah 3, no. 1 (June 29, 2018): 21-30, https://doi.org/10.24042/tadris.v3i1.2205; Nida Husna and Tahnia Lestari, "Empowering Character Building-Based Education: Discourse Analysis on Official English Textbook," TARBIYA: Journal of Education in Muslim Society 6, no. 1 (December 29, 2019): 58-68, https://doi.org/10.15408/tjems.v6i1.10354.

2 Muhammad Luthfi Abdullah and Akhmad Syahri, "Model of Religious Culture Education and Humanity," Nadwa 12, no. 2 (January 7, 2019): 331-44, https://doi.org/10.21580/nw.2018.12.2.2756.

3 Sadaf Umer Chhapra et al., "Analysis of Students Perception about Teachers' Personality in the Academic Achievement," TARBIYA: Journal of Education in Muslim Society 5, no. 1 (June 28, 2018): 101-15, https://doi.org/10.15408/tjems.v5i1.7098.

${ }^{4}$ Hamlan Andi Baso Malla, "Pembelajaran Pendidikan Agama Islam Berbasis Multikultural Humanistik Dalam Membentuk Budaya Toleransi Peserta Didik Di SMA Negeri Model Madani Palu, Sulawesi Tengah," INFERENSI: Jurnal Penelitian Sosial Keagamaan 11, no. 1 (June 1, 2017): 163-86, https://doi.org/10.18326/infsl3.v11i1.163-186; Ricky W. Griffin and Gregory Moorhead, Organizational Behavior: Managing People and Organizations (Cengage Learning, 2013).

${ }^{5}$ Etih Henriyani, "Pemimpin Dan Budaya Organisasi Di Era Perubahan,” Moderat 4, no. 2 (July 30, 2018): 61-71, https://jurnal.unigal.ac.id/index.php/moderat/article/view/1487.

6 Ari Kartiko and jaya Roza Azzukhrufi, "Pengaruh Budaya Organisasi Dan Kompensasi Terhadap Kinerja Pendidik Di Madrasah Aliyah Nahdlatul Ulama Mazro'atul Ulum Paciran," Nidhomul Haq: Jurnal Manajemen Pendidikan Islam 4, no. 2 (September 5, 2019): 207-26, https://doi.org/10.31538/ndh.v4i2.351; Dahlan Dahlan, Djamil Hasim, and Hamdan Hamdan, "Pengaruh Manajemen Sumber Daya Manusia Dan Budaya Organisasi Terhadap Kualitas Pelayanan Pada Kantor Kecamatan Tamalate Kota Makassar," Jurnal Ad'ministrare 4, no. 2 (2017): 69-75.

7 Zalik Nuryana, "Knowledge Management Sebagai Upaya Pengembangan Learning Organization Di Lembaga Pendidikan Islam," Literasi (Jurnal Ilmu Pendidikan) 8, no. 1 (September 5, 2017): 11-19, https://doi.org/10.21927/literasi.2017.8(1).11-19. 
Widodo ${ }^{8}$ in the research results showed that the ability of schools to change is determined by how empowered the school community is in making changes and managing change. These changes can occur within the environment itself or outside the school which has implications for the occurrence of changes within the school. Changes that occur in schools do not necessarily change, but there is a process of change in school culture. The success of changing school culture depends on change management. Therefore, it requires change management so that changes that occur in schools are really built together from the values of togetherness of all school members so that the impact of these changes can be directed at the point of positive change ${ }^{9}$.So far, many studies have concluded that a strong organizational culture will make members more satisfied, motivated and have a great commitment to the organization ${ }^{10}$. Besides that a strong organizational culture will be able to increase the commitment, enthusiasm, and loyalty of members of the organization, so that it is expected that a good culture will be able to have a positive impact on the progress of educational institutions ${ }^{11}$.

Sukadari et al in their research results showed that: 1) teachers and principals of SDN Kasihan Bantul have understood the culture of schools and character education; 2) The implementation of character education through school culture in integrating subjects with the values contained in character education has been going well and significantly with the development of student behavior; 3) Student activities have been going well, students can participate in intracuricular and extracurricular activities according to their talents and interests; 4) Relationships between school members are in a conducive and harmonious atmosphere $^{12}$.

Based on the results of the study that organizational culture has a significant influence on the effectiveness of an organization and its achievements. The application of the concept of organizational culture in schools/madrasa is actually not much different from the application of other organizational culture concepts. The existence of schools/madrasa as educational organizations has a role and function to try to develop, preserve and pass on cultural values to their students. The organizational culture in madrasas is a reflection of the framework for achieving the quality of education in madrasas. The values and beliefs in achieving the quality of education in schools are the main thing for all school residents in producing quality graduates and having high morals. The organizational culture of each school/madrasa is largely determined by the values that are the priority of each institution.

${ }^{8}$ Hendro Widodo, "Manajemen Perubahan Budaya Sekolah," Manageria: Jurnal Manajemen Pendidikan Islam 2, no. 2 (2017): 287-306.

9 Sudarwan Danim, Manajemen dan kepemimpinan transformasional kekepalasekolahan: visi dan strategi sukses era teknologi, situasi krisis, dan internasionalisasi pendidikan (Rineka Cipta, 2009).

${ }^{10}$ Ali Miftakhu Rosyad and Muhammad Anas Maarif, "Paradigma Pendidikan Demokrasi Dan Pendidikan Islam Dalam Menghadapi Tantangan Globalisasi Di Indonesia," Naz̧bruna: Jurnal Pendidikan Islam 3, no. 1 (February 7, 2020): 75-99, https://doi.org/10.31538/nzh.v3i1.491.

${ }^{11}$ Ester Manik and Kamal Bustomi, "Pengaruh Kepemimpinan Kepala Sekolah, Budaya Organisasi Dan Motivasi Kerja Terhadap Kinerja Guru Pada SMP Negeri 3 Rancaekek," Jurnal Ekonomi, Bisnis \& Entrepreneurship 5, no. 2 (2011): 97-107.

12 Sukadari Sukadari, Suyata Suyata, and Shodiq A. Kuntoro, "PENELITIAN ETNOGRAFI TENTANG BUDAYA SEKOLAH DALAM PENDIDIKAN KARAKTER DI SEKOLAH DASAR,” Jurnal Pembangunan Pendidikan: Fondasi Dan Aplikasi 3, no. 1 (July 1, 2015): 58-68, https://doi.org/10.21831/jppfa.v3i1.7812. 
The priority values are adjusted to the situation and condition of each organization, both schools and madrasas.

\section{METHOD}

This research uses qualitative research with a descriptive approach. researchers only describe and describe the existing phenomenon in the field. According to Creswell's direction that the key qualitative research instrument is this researcher himself $f^{13}$. The location and research site is Madrasah Ibtidaiyah (MI) Ma'arif NU Man'baur Rohmah in Kembangan Village, Kebomas District, Gresik Regency. Data collection through observation, interviews and documents. The informants in this study were the Principal of MI Ma'arif Manba'ur Rohmah, the teacher and student guardians.Researchers in conducting data analysis according to Miles and A. Huberman. With the following stages $\left.{ }^{14}: 1\right)$ Data Collection, is the stage of collecting data obtained from the results of interviews, observations, and documentation. 2) Data Reduction, the selection process, focusing on simplification, abstracting and transformation of "rough" data arising from written records in the field. 3) Presentation of Data, make meaning of data as a collection of information arranged that is used in drawing conclusions and taking action.

\section{LITERATURE REVIEW}

\section{Organization Culture and School Culture}

Koentjaraningrat states that culture is defined as the whole system of ideas of actions and results of human work in the context of community life which belongs to human beings by learning. From this understanding culture implies: 1) the existence of value patterns, behavioral attitudes including language, intentions and works; 2) culture is closely related to perceptions of values and their environment that give birth to meaning and outlook on life, which will influence attitudes and behavior; 3) culture is the result of life experiences, habits and the selection process of existing norms in the way he interacts socially or places himself in the midst of certain environments; 4) in the cultural process there is a process of mutual influence and interdependence, both social and non-social environment ${ }^{15}$.

Organizational culture is an inseparable part of the organization's internal environment because the cultural diversity that exists in an organization is the same as the number of individuals in the organization. In general, organizational culture is greatly influenced by the organization's external environment. According to Jones ${ }^{16}$, "organizational culture is the set of shared values and norms that controls organizational members interactions with each other and with suppliers, customers, and other people outside the organization". According to Mullins, "organizational culture is the collection of tradition, value, policies, beliefs, and attitudes that constitute a pervasive context for everything we do and think in an organization" ${ }^{\prime 17}$.

${ }^{13}$ John W. Creswell, Qualitative Inquiry \& Research Design: Choosing among Five Approaches, 2nd ed (Thousand Oaks: Sage Publications, 2007).

${ }^{14}$ Matthew B. Miles, A. M. Huberman, and Johnny Saldaña, Qualitative Data Analysis: A Methods Sourcebook, Third edition (Thousand Oaks, Califorinia: SAGE Publications, Inc, 2014).

${ }^{15}$ Koentjaraningrat, Kebudayaan, mentalitas dan pembangunan (Jakarta: Gramedia, 2000). 2008).

16 W. Jones and C. N. R. Rao, Supramolecular Organization and Materials Design (Cambridge University Press,

${ }^{17}$ Laurie J. Mullins, Essentials of Organisational Behaviour (Financial Times/Prentice Hall, 2008). 
Griffin and Moorhead ${ }^{18}$ discribe about culture organization as follow "Organization culture is the set of shared value, often taken for granted, that help people in an organization understand which actions are considered acceptable and which are considered unacceptable. Often these value are communicated through stories and other symbolic means". Schein also defines organizational culture as follows. "The culture of group can now be defined a pattern of shared basic assumptions that was learned by a group as it solved its problems of external adaption and internal integration, that has worked well enough to be considered valid and, therefore, to be taught to new members as the correct way to perceive, think, and feel in relation to those problem" ${ }^{\prime 19}$.

Luthan explained that there are six important characteristics of organizational culture namely; 1) obeserved behavioral regularities, that is, the regularity of the way members act that are observed. When members interact with other members of the organization, they might use common language, certain terms or rituals; 2) norms are various standards of behavior that are included including guidelines on the extent to which a job must be done; 3) dominant values; the existence of core values shared by all members of the organization for example about high product quality, low absenteeism or high efficiency; 4) philosophy, the existence of policies relating to organizational beliefs in treating customers and employees; 5) rules, the existence of strict guidelines, related to the progress of the organization; 6) organization climate, is an overall feeling which is described and conveyed through spatial conditions, how to interact with members of the organization, and the way organizational members treat themselves and customers or others ${ }^{20}$.

Krietner and Kinicki, there are four functions of organizational culture, namely: 1) Organizational Identity: giving organizational identity to employees by holding awards that encourage innovation, 2) Facilitating collective commitment: facilitating collective commitment, employees feel proud to be part of their organization. Employees feel they have many opportunities to do different jobs (innovation) and improve their careers and praise the greatness of their organizations, 3) Social system stability; promote social system stability. The stability of the social system reflects the degree to which the work environment is felt to be positive and supportive, and conflicts and changes are effectively managed, 4) Shape behavior by helping members make sense of their surroundings: forming behavior by helping superiors feel their existence. This cultural function helps employees understand why the organization does what it should do and how it intends to achieve short-term goals ${ }^{21}$.

Kasali, School culture is something that is built from the results of a meeting between the values held by the principal as a leader and the values shared by the teachers and employees in the school. These values are built by human thoughts in the school. The meeting of human thoughts then produces what is called an "organizational mind". From that organizational thought then emerges in the form of shared values, and then those values will become the main ingredients forming the school culture. From this culture, then appear in a variety of visible symbols and actions that can be observed and felt in everyday school life.

\footnotetext{
${ }^{18}$ Griffin and Moorhead, Organizational Behavior.

${ }^{19}$ Edgar H. Schein, Organizational Culture and Leadership (John Wiley \& Sons, 2016).

${ }^{20}$ Fred Luthans, Organizational Behavior (McGraw-Hill/Irwin, 2006).

${ }^{21}$ Robert Kreitner and Angelo Kinicki, Organizational Behavior (McGraw Hill/Irwin, 2004).
} 
Robbins $^{22}$ stated values are important for studying organizational behavior, because values lay the foundation for understanding attitudes and motivations and influencing the perceptions of people in the organization. Rokeach further stated that the value system is the principles and rules that can be learned in an organization to form someone to choose between alternatives, resolve conflicts, and make decisions ${ }^{23}$.

Values that become pillars of school culture can be prioritized on certain values. These priorities are then changed or can be exchanged with other values according to the focus of the institution's adaptation and the state of the institution's environment. Prioritized values include being innovative, adaptive, working hard, and caring for others. This condition may be very different from institutions that are focusing on external factors but with stable environmental conditions, the institution will be very suitable if it has a visionary school culture and people who understand their role in carrying out work. Prioritized values can include: discipline, honesty, simple relationships between people and sections, and broad insights. In institutions that are focusing on internal conditions with unstable environmental conditions, the institution will be very suitable if the values prioritized in school / madrasah culture are initiative, togetherness, responsibility, ownership, and commitment to the institution. Whereas institutions that focus on internal factors with stable environmental conditions can develop those that support cooperation and achieving effective and efficient goals. Prioritized values can include: cooperation, mutual understanding, the spirit of unity, obeying the principle, motivating, and guiding.

\section{Character Eucation}

Character education is a genuine effort to help someone understand, care, and act on the basis of core ethical values ${ }^{24}$. These ethical values in the grand theory of character education are developed in cultural education and national character which means religious, honest, tolerance, discipline, hard work, creative, independent, democratic, curiosity, national spirit, love of the motherland, respect for achievement, friendly, love peace, love to read, care about the environment, care about social, and responsibility ${ }^{25}$. Based on the above understanding, it can be understood that character is identical with morals, so that characters are universal human behavioral values which include all human activities, both in the context of relating to God, with himself, with fellow human beings, and with their environment, manifested in the mind, attitudes, feelings, words, and actions based on religious norms, law, manners, culture, and customs ${ }^{26}$.

According to the Ministry of National Education, there are 18 values of character education, namely: 1) Religious; 2) Honestly; 3) Tolerance; 4) Discipline; 5) Hard work; 6) Creative; 7) Independent; 8) Democratic; 9) Curiosity; 10) Nationalism or nationalism; 11) Love the motherland; 12) Appreciate achievement; 13) Communicative; 14) Peace in love; 15)

22 Stephen P. Robbins and Tim Judge, Organizational Behavior (Pearson/Prentice Hall, 2007), 6.

${ }^{23}$ Milton Rokeach, Understanding Human V alues (Simon and Schuster, 2008).

${ }^{24}$ Thomas Lickona, Educating for Character: How Our Schools Can Teach Respect and Responsibility (New York: Bantam Books, 2009), 7.

${ }_{25}$ Samani Muclas and Hariyanto, Konsep dan Model Pendidikan karakter, 6th ed. (Bandung: Rosdakarya, 2017); E Mulyasa, Manajemen Pendidikan Karakter, 5th ed. (Jakarta: Bumi Aksara, 2016).

${ }^{26}$ Jauhar Fuad, "Pendidikan Karakter Dalam Pesantren Tasawuf," Jurnal Pemikiran Keislaman 23, no. 1 (2013); Subaidi, Abdul Wahab Asy-Sya rani, Sufisme dan Pengembangan Pendidikan Karakter (Yogyakarta: Anggota Ikapi, 2015). 
Love reading; 16) Care for the environment; 18) Responsibility.

\section{RESULT AND DISCUSSION}

Madrasah Ibtidaiyah (MI) Ma'arif NU Manbaur Rohmah in realizing the commitment to provide the best education for their students to form a generation of Islamic character and environmentally sound based on the Qur'anic spirit is achieved, then the vision is" Making a qualified, creative generation, mastering science and technology, environmentally based on the spirit of the Qur'an ". In supporting the achievement of the MI Ma'arif NU Manba'ur Rohmah Vision, it is necessary to establish a mission to support the achievement of the Vision. Its mission is: 1) To meet the 8 national education standards set by the government; 2) building intelligent, creative and capable students; 3) Building a religious culture that is reflected in daily habits; 4) Carry out SCEIJOL learning (Student Creative, Effective, Innovative, and Joyful Learning); 5) Carry out optimal coaching both in the academic field and self-development; 6) Giving birth to graduates who have noble character, love the motherland, are smart, creative and capable; 7) Intensively develop the spirit of excellence to all madrasa residents; 8) Forming Islamic students who are in accordance with Aswaja Annahdliyah; 9) Creating a school environment free of plastic waste as an effort to protect against environmental pollution; 10) Prevent pollution and damage to the environment with $4 \mathrm{R}$ (reduce, reuse, recycle, and repleace); 11) Realizing efforts to preserve the school environment with green \& cleen programs, beautiful and healthy.

Various efforts undertaken by madrassas in growing character in students, from the re sults of interviews conducted with the Principal of Madrasah Ibtidaiyah Manba'ur Rohmah, Hamida said:

"In growing the character of students through compassion for God and the Prophet, love for parents and teachers, compassion for others, love for oneself, affection in achieving excellence, compassion in reaching science and technology, compassion for nature, compassion towards the Nation and State "

Based on statements made by Hamida that in growing compassion for Allah and the Prophet the indicators are students in performing prayers with solemnity and discipline, purifying with orderly, reciting in an orderly manner every day, performing istighotsah with khusyu ', praying at the start and ending each activity, behaving honestly, following the commemoration of the Islamic Great Day.

Furthermore, fostering affection for parents and teachers the indicators are students behaving politely to parents, behaving politely to teachers, serving parents, serving teachers, being disciplined in attending classes, asking for permission when not entering school or going home before the end of class. Cultivating affection for others through the provision of understanding about visiting guests, mutual respect for fellow friends, empathizing with others both within the school environment and family environment and community environment.

Cultivating affection for yourself through understanding in wearing a full, neat, and clean uniform in accordance with the provisions in the school. Maintain personal hygiene, do all the tasks of the teacher, put and arrange shoes neatly in place, get used to discipline in line, do morning exercises seriously, carry out picket with responsibility, courtesy inside and outside of school, ask or answer the question politely. Cultivating affection in achieving excellence through understanding students about active participation in extracurricular activities that must be followed through student choices is allowed more than one with a record of time 
does not coincide, motivation and never give up in achieving achievements by teachers and parents. Compassion in reaching science and technology through understanding students about the proper use of technology both at home and at school, active in literacy activities in the classroom and library.

In fostering a sense of compassion for nature through understanding students in maint aining environmental cleanliness in the classroom and at school, maintaining the beauty of the park and care for the surrounding environment. Interviews were also conducted with the hom eroom teacher Miss Erna, conveying that;

"In shaping the character of students, it needs support from various parties,

both teachers and parents through the book monitoring morality of mercy and

loving care. Monitoring is carried out by the teacher as the homeroom teacher and parents together in realizing the Vision of MI Ma'arif NU Manba'ur Rohmah "

The statement delivered by Ms. Erna that in shaping the character of students also needed support from various parties both teachers in the school as well as all parents through books prepared by the school, namely the book monitored morality mercy Mimbar Loving. With the book Mimbar Loving Love as a guide for teachers as homeroom teachers and parents together in realizing the vision of MI Ma'arif NU Manba'ur Rohmah is "Making a generation of quality, creative, mastering science and technology, environmentally friendly with based on the qur'ani soul".

\section{School Culture o Building Character Student}

The culture that is implemented at MI Ma'arif NU Manba'ur Rohmah so that students are accustomed to religious matters in daily habits through: Qur'an day, dhuba prayer, istighostah, literacy. Qur'an day is done every day for students ranging from class I to class VI, this culture is done to get students used to reading the Koran every day. Students who are in Madrasah Ibtidaiyah are students who are in primary education, at that time it was an early period in building the scientific foundation of our students with routine learning of reading the Qur'an in forming students with Islamic character. The picture below is a documentation of students' activities in the Koran day under the supervision of their homeroom teacher.

Figure 1: Koran day: habituation every day in the madrasa

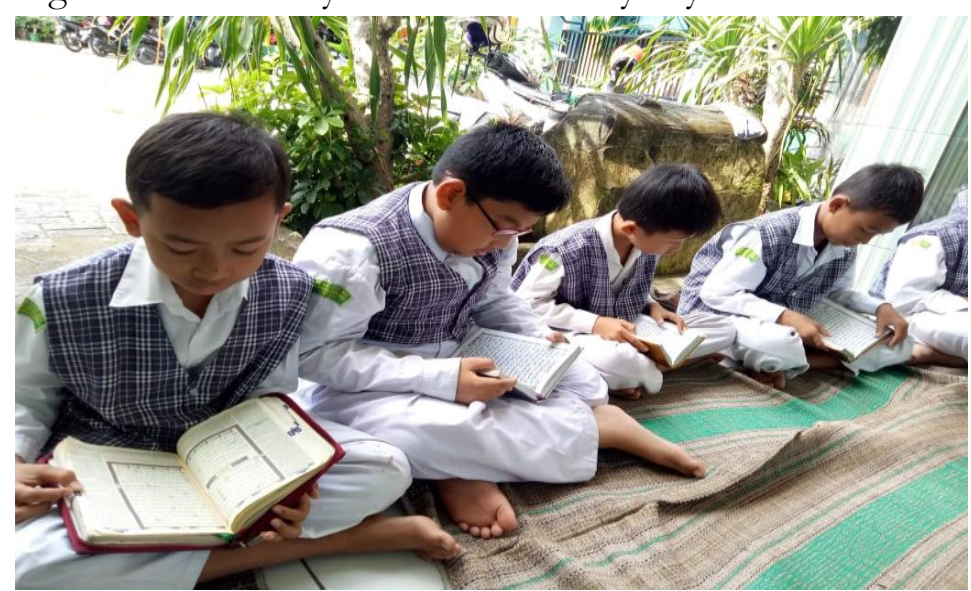

Source: Documentation at MI Ma arif NU Manba ur Rohmah

In educating students to always pray Duha, it is also done every day on students starting from class I to class VI, this culture is done to get students to always do Duba prayer every day. in forming students with Islamic character. The picture below is a documentation 
of student activities in the Duha prayer activities under the supervision of their homeroom teacher.

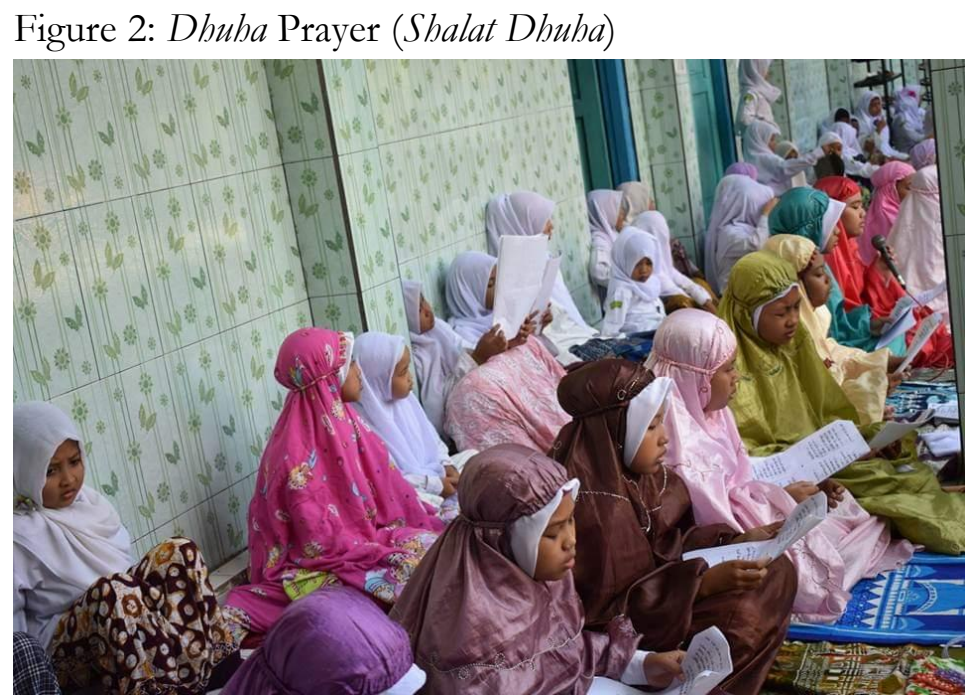

Source: Documentation at MI Ma`arif NU Manba `ur Rohmah

Istighotsah is conducted every month in order to provide learning to students ranging from class I to class VI to always pray to God, this culture is done to get students used to always ask for help from God when conditions are difficult and difficult. Familiarizing children who are still studying in Madrasah Ibtidaiyah is an early period in building the scientific foundation of our students with routine learning to always pray to God. The picture below is a documentation of student activities in the application of istighotsah culture in madrasas in shaping the Islamic character of students.

Figure 3: Istighasah every month

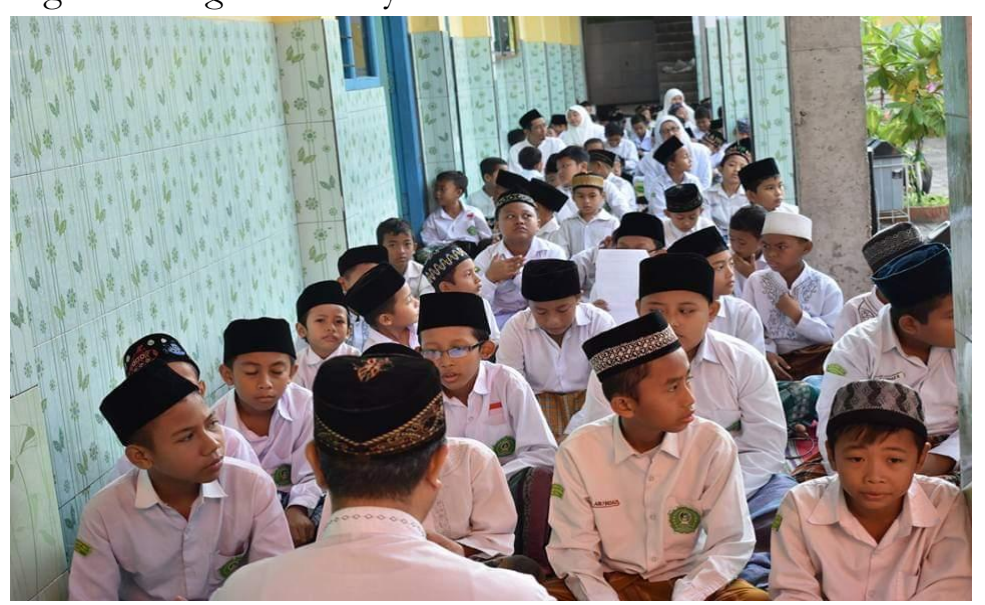

Source: Documentation at MI Ma arif NU Manba ur Rohmah

Literacy activities are carried out every day effectively entering school, carried out in the reading corner of each classroom and also carried out in the library in accordance with the instructions of the homeroom teacher responsible for students in the class. The activity is carried out with the aim to familiarize the culture of reading to students so that students feel that reading can add insight into knowledge. Below is a document on the activities of grade 5 students who are currently literating in the library room. 
Figure 4: Literacy at madrasa library

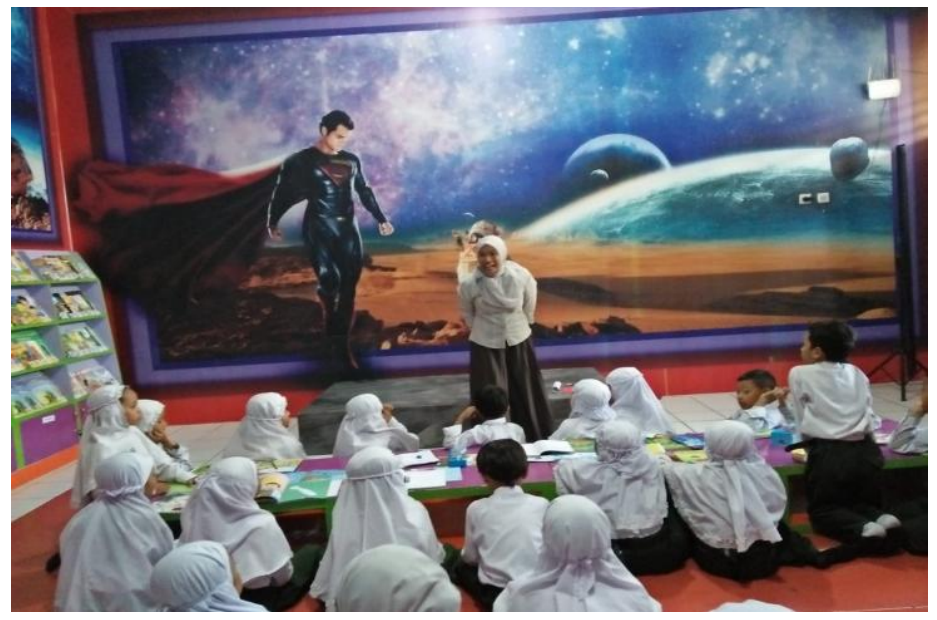

Source: Documentation at MI Ma arif NU Manba `ur Rohmah

Interviews were also conducted with students' parents, Ibu Suhariyanti, said that;

"I really believe in MI Ma'arif NU Manba'ur Rohmah, because I always familiarize my children to do Duha prayers, recite the Koran and do Istighosah so that my children understand religious knowledge"

The statement delivered by Ibu Suhariyanti as parents of students believes that MI Ma'arif NU Manba'ur Rohmah is an institution that is believed to be able to educate their children to be children who have good character, as a mental provision for children so they can understand religious knowledge. In educating students at MI Ma'arif NU Manba'ur Rohmah always accustoming students to always do the Duha prayer every day before school learning begins, accustom students to study every morning in accordance with the schedule that has been made by their homeroom teacher, also accustom istighosah a routine scheduled by the madrasa as a form of learning that shapes students' personalities.

In a highly competitive environment with a very rapid development of the environment, madrassas must be able to develop innovative, adaptive values, work hard, and care for others. Innovative values are important to always encourage all madrasa human resources in producing new products to always be able to compete with other madrassas / schools that are competitors. Adaptive value is used to encourage the ability of all human resources in madrasas to always be able to change to adjust to the evolving trends and in accordance with the expectations of stakeholders who are always changing. The value of working hard, will encourage madrasas to have high productivity and high productivity will push madrasas to excel. The value of caring, Human Resources in madrasas are required to be able to govern themselves or control themselves.

Madrasa culture is something that is built from the results of the meeting between the values held by the principal as a leader with the values shared by the teachers and employees in the school/madrasah ${ }^{27}$. These values are built by human thoughts in the school/ madrasa. The meeting of human thoughts then produces what is called an "organizational mind". From that organizational thought then emerges in the form of shared values, and then those values will

${ }_{27}$ Muhammad Anas Maarif et al., "Character Education Through Dhikr Tariqa Qadiriyya Naqhsabandiyya Al-Usmaniyya Indonesia,” Hampstead Psychological Associates 24, no. 07 (2020): 9. 
become the main ingredients forming the school/madrasah culture ${ }^{28}$.

\section{CONCLUSSION}

Madrasah Ibtidaiyah (MI) Ma'arif NU Manba'ur Rohmah to building character of students through the book monitoring morality of mercy Standing Love, which includes: love for God and the Prophet, love for parents and teachers, compassion for others, compassion for yourself, compassion in achieving excellence, compassion in reaching science and technology, compassion for nature, affection for the Nation and State. Building the character through madrasa culture, namely: 1) Koran day, this culture is done to get students accustomed to reading the Koran every day; 2) Dhuba prayer, culture to accustom students to always do Dhuha prayer every day; 3) Istighotsah, culture to accustom students to always pray closer to God; 4) Literacy, the culture of reading is instilled in students so that reading can add insight into knowledge.

\section{REFERENCES}

Abdullah, Muhammad Luthfi, and Akhmad Syahri. "Model of Religious Culture Education and Humanity." Nadwa 12, no. 2 (January 7, 2019): 331-44. https://doi.org/10.21580/nw.2018.12.2.2756.

Abdullah, Mukhammad. "School Culture to Serve Performance of Madrasah in Indonesia." QIJIS (Qudus International Journal of Islamic Studies) 7, no. 1 (June 3, 2019): 71. https://doi.org/10.21043/qiiis.v7i1.4809.

Baharun, Hasan, and Rohmatul Ummah. "Strengthening Students' Character in Akhlaq Subject Through Problem Based Learning Model." Tadris: Jurnal Keguruan Dan Ilmu Tarbiyah 3, no. 1 (June 29, 2018): 21-30. https://doi.org/10.24042/tadris.v3i1.2205.

Chhapra, Sadaf Umer, Saba Naz, Mehmood Usmani, and Adil Mohiuddin. "Analysis of Students Perception about Teachers' Personality in the Academic Achievement." TARBIYA: Journal of Education in Muslim Society 5, no. 1 (June 28, 2018): 101-15. https://doi.org/10.15408/tjems.v5i1.7098.

Creswell, John W. Qualitative Inquiry \& Research Design: Choosing among Five Approaches. 2nd ed. Thousand Oaks: Sage Publications, 2007.

Dahlan, Dahlan, Djamil Hasim, and Hamdan Hamdan. "Pengaruh Manajemen Sumber Daya Manusia Dan Budaya Organisasi Terhadap Kualitas Pelayanan Pada Kantor Kecamatan Tamalate Kota Makassar.” Jurnal Ad'ministrare 4, no. 2 (2017): 69-75.

Danim, Sudarwan. Manajemen dan kepemimpinan transformasional kekepalasekolahan: visi dan strategi sukses era teknologi, situasi krisis, dan internasionalisasi pendidikan. Rineka Cipta, 2009.

E Mulyasa. Manajemen Pendidikan Karakter. 5th ed. Jakarta: Bumi Aksara, 2016.

Fuad, Jauhar. "Pendidikan Karakter Dalam Pesantren Tasawuf." Jurnal Pemikiran Keislaman 23, no. 1 (2013).

${ }^{28}$ Mukhammad Abdullah, "School Culture to Serve Performance of Madrasah in Indonesia," QIJIS (Qudus International Journal of Islamic Studies) 7, no. 1 (June 3, 2019): 71, https://doi.org/10.21043/qijis.v7i1.4809; Nur Khoiri, "Madrasah Culture Based Transformational Leadership Model," Nadwa : Jurnal Pendidikan Islam 10 (October 2016): 151-74, http://journal.walisongo.ac.id/index.php/nadwa. 
Griffin, Ricky W., and Gregory Moorhead. Organizational Behavior: Managing People and Organizations. Cengage Learning, 2013.

Haviz, M., Afwadi Afwadi, Kasmuri Selamat, Ika Metiza Maris, Akhyar Hanif, Ridwal Trisoni, and Yusrizal Effendi. "Investigating Students Knowledge and Social Awareness of the Community of Religious Social Activist Minangkabau: A Community Based Reseach In West Sumatra, Indonesia." TARBIY A: Journal of Education in Muslim Society 6, no. 1 (December 29, 2019): 10-22. https://doi.org/10.15408/tjems.v6i1.8657.

Henriyani, Etih. "Pemimpin Dan Budaya Organisasi Di Era Perubahan." Moderat 4, no. 2 (July 30, 2018): 61-71. https://jurnal.unigal.ac.id/index.php/moderat/article/view/1487.

Husna, Nida, and Tahnia Lestari. "Empowering Character Building-Based Education: Discourse Analysis on Official English Textbook." TARBIYA: Journal of Education in Muslim Society 6, no. 1 (December 29, 2019): 58-68. https://doi.org/10.15408/tjems.v6i1.10354.

Jones, W., and C. N. R. Rao. Supramolecular Organization and Materials Design. Cambridge University Press, 2008.

Kartiko, Ari, and jaya Roza Azzukhrufi. "Pengaruh Budaya Organisasi Dan Kompensasi Terhadap Kinerja Pendidik Di Madrasah Aliyah Nahdlatul Ulama Mazro'atul Ulum Paciran." Nidhomul Haq: Jurnal Manajemen Pendidikan Islam 4, no. 2 (September 5, 2019): 207-26. https://doi.org/10.31538/ndh.v4i2.351.

Khoiri, Nur. "Madrasah Culture Based Transformational Leadership Model." Nadwa: Jurnal Pendidikan Islam $10 \quad$ (October 2016): 151-74. http://journal.walisongo.ac.id/index.php/nadwa.

Koentjaraningrat. Kebudayaan, mentalitas dan pembangunan. Jakarta: Gramedia, 2000.

Kreitner, Robert, and Angelo Kinicki. Organizational Behavior. McGraw Hill/Irwin, 2004.

Lickona, Thomas. Educating for Character: How Our Schools Can Teach Respect and Responsibility. New York: Bantam Books, 2009.

Luthans, Fred. Organizational Behavior. McGraw-Hill/Irwin, 2006.

Maarif, Muhammad Anas, Muhammad Mujtaba Mitra Zuana, Siti Maryam Munjiat, Ibnu Rusydi, Ali Miftakhu Rosyad, and Lu'lu'il Maknuun. "Character Education Through Dhikr Tariqa Qadiriyya Naqhsabandiyya Al-Usmaniyya Indonesia." Hampstead Psychological Associates 24, no. 07 (2020): 9.

Malla, Hamlan Andi Baso. "Pembelajaran Pendidikan Agama Islam Berbasis Multikultural Humanistik Dalam Membentuk Budaya Toleransi Peserta Didik Di SMA Negeri Model Madani Palu, Sulawesi Tengah.” INFERENSI: Jurnal Penelitian Sosial Keagamaan 11, no. 1 (June 1, 2017): 163-86. https://doi.org/10.18326/infsl3.v11i1.163-186.

Manik, Ester, and Kamal Bustomi. "Pengaruh Kepemimpinan Kepala Sekolah, Budaya Organisasi Dan Motivasi Kerja Terhadap Kinerja Guru Pada SMP Negeri 3 Rancaekek." Jurnal Ekonomi, Bisnis \& Entrepreneurship 5, no. 2 (2011): 97-107.

Miles, Matthew B., A. M. Huberman, and Johnny Saldaña. Qualitative Data Analysis: A Methods Sourcebook. Third edition. Thousand Oaks, Califorinia: SAGE Publications, Inc, 2014.

Muclas, Samani, and Hariyanto. Konsep dan Model Pendidikan karakter. 6th ed. Bandung: Rosdakarya, 2017.

Mullins, Laurie J. Essentials of Organisational Behaviour. Financial Times/Prentice Hall, 2008. 
Nuryana, Zalik. "Knowledge Management Sebagai Upaya Pengembangan Learning Organization Di Lembaga Pendidikan Islam.” Literasi (Jurnal Ilmu Pendidikan) 8, no. 1 (September 5, 2017): 11-19. https://doi.org/10.21927/literasi.2017.8(1).11-19.

Robbins, Stephen P., and Tim Judge. Organizational Behavior. Pearson/Prentice Hall, 2007.

Rokeach, Milton. Understanding Human V alues. Simon and Schuster, 2008.

Rosyad, Ali Miftakhu, and Muhammad Anas Maarif. "Paradigma Pendidikan Demokrasi Dan Pendidikan Islam Dalam Menghadapi Tantangan Globalisasi Di Indonesia.” Naz̧bruna: Jurnal Pendidikan Islam 3, no. 1 (February 7, 2020): 75-99. https://doi.org/10.31538/nzh.v3i1.491.

Schein, Edgar H. Organizational Culture and Leadership. John Wiley \& Sons, 2016.

Subaidi. Abdul Wabab Asy-Sya rani, Sufisme dan Pengembangan Pendidikan Karakter. Yogyakarta: Anggota Ikapi, 2015.

Sukadari, Sukadari, Suyata Suyata, and Shodiq A. Kuntoro. "PENELITIAN ETNOGRAFI TENTANG BUDAYA SEKOLAH DALAM PENDIDIKAN KARAKTER DI SEKOLAH DASAR.” Jurnal Pembangunan Pendidikan: Fondasi Dan Aplikasi 3, no. 1 (July 1, 2015): 58-68. https://doi.org/10.21831/jppfa.v3i1.7812.

Widodo, Hendro. "Manajemen Perubahan Budaya Sekolah." Manageria: Jurnal Manajemen Pendidikan Islam 2, no. 2 (2017): 287-306. 